\title{
CAJUEIRO REVISITADO: OU DEZ ANOS DE RELATO CRÍTICO EM CONSTRUÇÃO
}

\section{CAJUEIRO REVISITED: OR TEN YEARS OF CRITICAL REPORT UNDER BUILDING}

\author{
Bartolomeu Rodrigues Mendonça* \\ Samarone Carvalho Marinho**
}

\section{Preâmbulo}

Este breve artigo, muito embora traga no título a comunidade Cajueiro, expõe processos de resistências e lutas por direitos territoriais de pelo menos outras vinte comunidades, localizadas no município de São Luís, capital do estado do Maranhão. Todas essas comunidades, com maior ou menor intensidade, possuem características territoriais, econômicas e culturais semelhantes e, por isso, extrapolam a conformidade político-administrativa dada aos seus espaços de vivência.

0 processo de luta das comunidades para permanência nos seus territórios seculares, no município de São Luís, antecede a década de 1970, quando muitas delas resistiram à chegada de empresas industriais, de logística e de infraestrutura de transporte terrestre e marítimo (ANDRADE, 1981; GISTELINCK, 1988; FERREIRA, 1997; MENDONÇA, 2006). Revisitar a última década, entretanto, constitui um balanço das pesquisas e dos trabalhos de extensão realizados pelo Grupo de Estudos: Desenvolvimento, Modernidade e Meio Ambiente (GEDMMA), que se forjou também nas lides de resistência dessas comunidades. 0 "caso" Cajueiro aqui revisto, por exemplo, remonta ao enfrentamento de investidas governamentais e privadas que, atendendo à lógica de desarticulação de territórios, propuseram-se à prática de expulsão/repulsão de moradores de suas terras para a construção de um polo siderúrgico. 0 resultado seria a constituição

\footnotetext{
* Sociólogo, Professor. Colun/UFMA - (São Luís/MA/Brasil), doutorando em Ciências Sociais pela Universidade Federal do Maranhão - UFMA (São Luís/MA/Brasil), Coordenação GEDMMA. canapum@gmail.com. ** Professor do Departamento de Geociências da Universidade Federal do Maranhão - UFMA (São Luís/ MA/Brasil), doutor em Geografia Humana pela Universidade de São Paulo, Coordenação GEDMMA. samaronemarinho@hotmail.com.
} 
de um complexo industrial que comportaria três grandes usinas siderúrgicas de bandeiras alemã, chinesa e coreana, respectivamente - Thyssenkrupp, Baosteel e Posco (ZAGALLO, 2004; MENDONÇA, 2006).

Desde 2002, os jornais locais veiculavam as movimentações conjuntas do governo do estado do Maranhão com a então Companhia Vale do Rio Doce (CVRD) - hoje somente Vale - para arranjar parcerias com o capital internacional com o propósito de materializar o extinto Projeto Ferro Carajás, que previa a instalação de usinas siderúrgicas na Ilha do Maranhão (GISTELINCK, 1988; MENDONÇA, 2006). ${ }^{1}$ Entretanto, foi a partir de 2004 que as comunidades passaram a perceber e sentir mais objetivamente as ameaças de perda dos seus territórios para o projeto do polo siderúrgico. Desde então, comunidades, pesquisadores e sociedade civil organizada passaram ao enfrentamento a fim de evitar aquilo que muitos classificaram como o que seria uma verdadeira catástrofe social e ambiental para o já debilitado sistema insular de São Luís (ZAGALLO, 2004).

Essa trama coincidiu com as movimentações de um pequeno grupo de estudantes e docentes do curso de Ciências Sociais da Universidade Federal do Maranhão (UFMA), inquietos por fazer ciência engajada com o devido rigor do método acadêmico, com sentido emancipatório, bem distante da suposta imparcialidade. Daí, como tubo de ensaio, o recém-criado e ainda cambaleante grupo de estudos GEDMMA resolveu acompanhar os processos de luta e resistência das comunidades ameaçadas de deslocamento compulsório pelo projeto assinado pelos governos municipal e estadual, e pela multinacional Vale.

A formalização das atividades do grupo GEDMMA se dá em 2005, com o projeto "Modernidade, Desenvolvimento e Consequências Socioambientais: a implantação do polo Siderúrgico na Ilha de São Luís - MA”, vigente até 2009. Nos anos seguintes, o grupo de estudos desenvolveu diversos projetos de pesquisa e extensão, alguns já fınalizados e outros em andamento, todos com o apoio de agências públicas de fomento à pesquisa. Pode-se destacar, também, que nos dois últimos anos (2014-2015) o grupo de estudos aprofundou relações de cooperação com instituições de ensino nacionais e internacionais. É nesse prisma de atuação que o GEDMMA vem acompanhando processos de sociabilidade decisivos, que ganham fôlego na forma de elaboração e publicação de relatórios técnicos, livros, monografias, dissertações e teses.

Poder-se-ia então pensar que este artigo seria uma espécie de síntese. Em absoluto, não; tampouco, uma pincelada final. Este artigo quer ser tão somente um relato crítico das conquistas, dos ganhos, dos avanços e dos recuos desses processos que não se encerram porque são atravessados (e atravessam) pelas (as) vidas de milhares de pessoas neles entrelaçadas. Constitui-se, tão somente, em mais um passo. Um passo que é a expressão de um breve relato de resistência.

\footnotetext{
1. A Ilha do Maranhão é uma ilha no nordeste maranhense, localizada na baía de São Marcos, que abriga quatro municípios: São Luís (capital do estado), São José de Ribamar, Paço do Lumiar e Raposa. De maneira usual e corrente, os populares e mesmo os estudiosos e órgãos públicos denominam-na de Ilha de São Luís. Portanto, neste trabalho, Ilha do Maranhão e Ilha de São Luís são o mesmo território, o mesmo espaço geográfico e político.
} 


\section{Introdução}

As comunidades rurais da parte sudoeste da Ilha do Maranhão, ${ }^{2}$ no município de São Luís, vivem em um território secularmente construído à base da economia da pesca, da agricultura familiar, do pequeno comércio, dos trabalhos formais e informais sazonais, com estrutura social assentada nas relações de parentesco e de compadrio que favorecem as trocas solidárias de trabalho, alimentos, ritos, festas, saberes.

Esse território ancestral - um mosaico de comunidades pesqueiras, agrícolas, festeiras, religiosas - tem sido, ao longo dos anos, suprimido pelo avanço da urbanização, industrialização e especulação fundiária. Datam dos anos 1970 as primeiras investidas, mais sistemáticas e com a participação efetiva do Estado, para desmantelar as condições de permanência e reprodução material e cultural das comunidades.

Os equipamentos urbanos de garantia de saúde, educação, segurança pública e transporte praticamente inexistem, e os governos que se sucederam (seja em âmbito municipal ou estadual) deliberadamente optaram em não fazer qualquer investimento significativo para levar estruturas básicas mínimas que garantissem a permanência das comunidades nos seus territórios. Em todo esse tem- po, o que se viu foi esses governos deixarem as comunidades em estágio de precarização material tal que forçava os mais jovens a sair de seu entorno para concluir os estudos secundários, e toda a comunidade a buscar assistência à saúde em unidades distantes e de difícil acesso.

Mesmo nesse cenário de abandono, as comunidades organizadas em grupos, associações e cooperativas lutam irmanadas há décadas para garantir o título das suas terras, investimentos para suas atividades de lavoura e pesca, e melhorias dos serviços públicos de modo geral. Como resposta, os sucessivos governos municipais e estaduais, associados aos grandes empreendimentos, muito pouco têm trabalhado para que as condições dos serviços públicos melhorem, o que, em muito, implica o aumento da insegurança fundiária. Entretanto, a história recente mostra a capacidade de organização e de resistência dessas comunidades na luta em defesa dos seus territórios. E, atualmente, a sanha oficial avança sobre toda a cidade, toda a ilha. É isso que discutimos a seguir.

\section{Cajueiro e comunidades irmãs, ${ }^{3}$ luta contra o polo siderúrgico}

Cajueiro situa-se na porção sudoeste do município de São Luís e forma, com cerca

2. [...] tal como assinalada por diferentes estudiosos de comunidades rurais em processo de mudanças sociais, cujas relações são caracterizadas pelas noções de 'ambientes de vida' (HÉBETTE, 2004), 'meios de vida' (CÂNDIDO, 1978), podendo ser sintetizadas na defınição de Meyer (1979, p. 16) em seu estudo sobre 'uma comunidade rural nordestina' quando diz: 'a configuração de uma comunidade no espaço só ganha significado quando percebida à luz de um sistema de relações sociais que articula não só os elementos internos à comunidade, mas também, esses elementos àqueles que são externos”' (ALVES, 2014, p. 29).

3. "As localidades afetadas eram em geral designadas por 'povoados', enquanto, as lideranças a elas se referiam usando o termo 'comunidades'. 0 uso dos termos 'povoado' e 'comunidade' ajudaram a conferir identidade distintiva a esses territórios historicamente ocupados pela população local e a fazer reconhecer a noção de que neles havia um 'modo de vida' a ser defendido. Além disso, esses termos revelaram também as distinções, sobretudo quanto ao histórico do processo de ocupação, de uso da terra e na forma de sociabilidade e coesão interna, assim como, as relações entre os diferentes núcleos de povoamento" (AL- 
de vinte outras comunidades, um território de características bem distintas das da zona urbana. A constituição básica de seu processo de povoamento historicamente privilegiou a prática da lavoura e da pesca como meios de vida (MENDONÇA, 2006).

0 território formado pelas comunidades da porção sudoeste, ao qual Cajueiro pertence, é constituído também pelas comunidades Rio dos Cachorros, São Joaquim, Sítio Livramento, Santa Cruz, Limoeiro, Taim, Porto Grande, Estiva, Pedrinhas, Murtura, Matinha, Rio Grande, Vila Collier, Vila Maranhão, Sítio São Benedito, Mãe Chica, Vila Conceição, Camboa dos Frades, Portinho, Ilha Pequena, Embaubal, Jacamim, Amapá e Tauá-Mirim (GEDMMA, 2014). A maioria dessas comunidades foi "incluída" na matriz de desenvolvimento do estado a partir das obras da então estrada de ferro Carajás, que liga as minas de minério de ferro, na Serra dos Carajás, no Pará, ao porto do Itaqui, em São Luís. Essa obra dividiu as comunidades, aumentou os níveis de poeira, assoreou ou obstruiu rios e suas nascentes, interferiu na produção local. Isso tudo em contradição aos alardes de que a estrada de ferro Carajás viria também trazer melhorias nos serviços púbicos, o que em geral não ocorreu (GISTELINCK, 1988).

0 acesso para o Cajueiro se faz pelo ramal que interliga a BR-135 ao Porto do Itaqui, por uma estrada de solo exposto que corta a linha férrea e dista cerca de três quilômetros, sendo conhecida popularmente como "Estrada do Cajueiro". Segundo os moradores, a linha de ônibus que atende à Vila Maranhão foi estendida e passou a trafegar diariamente na Estrada do Cajueiro com frequência de duas horas, encerrando às $21 \mathrm{~h}$. Os moradores ainda reclamam do transporte e lembram que a precariedade do serviço é justificada pelos empresários do setor, por afirmarem que a comunidade não possui demanda de passageiros que garanta o retorno financeiro a eles. ${ }^{4}$

A reconstituição dos sucessivos processos de ocupação do território é bastante controversa. Segundo levantamento de empresa contratada pela Vale, a ocupação da comunidade Cajueiro remonta à década de 1930, antes mesmo da implantação dos grandes projetos de desenvolvimento, o que nos leva a conjecturar que, após essa década, um incessante quadro de disputa fundiária lá se agudizou. Vislumbra-se aqui, como demonstrativo desse quadro exposto no relatório "Diagnóstico Sócio-Organizativo” (DIAGONAL, 2005), que a posse de terra tem como marco oficial o ano de 1998; à referida comunidade foi dado o domínio útil de 610,0172 ha, englobando um total de 103 moradores.

Esse levantamento seletivo, entretanto, exclui da história do Cajueiro que este fora território de ancestralidade africana:

As ruínas do antigo Terreiro do Egito estão localizadas no território de Cajueiro, ${ }^{5}$ encravado numa elevação próxima ao Porto do Itaqui. Nos dias de festa, segundo relatos coletados, avistava-se o navio encantado

VES, 2014, p. 24). E sobre o processo de sociabilidade entre as comunidades mais antigas da área rural II de São Luís, sugere-se a dissertação de Sislene Costa da Silva, "Filhos do Taim: estratégias para defesa e uso de um território" (SILVA, 2009).

4. Informações colhidas junto aos moradores e em observações in loco. Passada uma década, as condições precárias permanecem.

5. Em 2013, o Instituto do Patrimônio Histórico e Artístico Nacional (Iphan) abriu o processo de registro do Terreiro do Egito como sítio arqueológico (cf. BRASIL, 2014, p. 255). 
do Rei Dom João. Segundo Pai Euclides, era chamado de Ilê Niame e teria sido fundado pela negra africana Basília Sofia, cujo nome privado era Massinocô Alapong, ${ }^{6}$ vinda de Cumassi, na Costa do Ouro - atual Gana. Ela teria chegado ao Maranhão em 1864 e falecido em 1911 (GEDMMA, 2014, p. 5).

0 território do Cajueiro, portanto, apresenta espacialidades e temporalidades sobrepostas, que vão de lugar sagrado religioso - terreiro de Mina mais antigo do país, datado de 1864, abrigo de escravos fugidos -, até uma história de recente ocupação.

Seja como for, recorrendo à memória dos moradores mais antigos dessa mais recente ocupação, a comunidade passa a se organizar com a chegada de um homem conhecido como Boa Ventura, cuja história de vida nos foi revelada por uma de suas filhas, a Sra. Dora. Ela, então com 79 anos, era a pessoa que morava há mais tempo em Cajueiro, embora não fosse a mais velha da comunidade. Ela lembra que:

\footnotetext{
A idade que eu tive foi de 10 anos, e nós morava ali na Camboa do Itaqui, ${ }^{7}$ aí viemos pra cá trabalhar, chegamos aqui papai se agradou muito daqui e resolveu morar, aí foi lá na Vila, que lá tinha um senhor que tomava conta aqui, que era o vigia daqui, aí ele foi pediu pra gente vir morar aqui, ele mandou, aí nós ficamos morando (informação verbal) ${ }^{8}$.
}

Mesmo fixando residência, esses moradores não se consideravam donos de fato da terra. Diz o senhor Aparecido: “a gente mora aqui esses anos tudinho, mas dono mesmo a gente não é não. Eu não sei quem é o dono, não". Outros dizem que as terras são do governo do estado; conforme a senhora Estela relata: "Estas terras, nós vivemos muitos anos nelas, mas elas são mesmo é do estado".

Cajueiro tem área total de 600 hectares, com uma população de 1.600 habitantes e 265 prédios edificados no bairro. Entre essas edificações, destacam-se as seguintes instituições: Escola Municipal Manuela Varella, que oferece educação infantil e ensino fundamental (da $1^{\text {a }}$ à $4^{\text {a }}$ séries); o Clube de Mães Nossa Senhora do Perpétuo Socorro; a União dos Moradores Proteção de Jesus do Cajueiro; a Igreja Católica Nossa Senhora do Perpétuo Socorro (que utiliza as instalações da União, pois seu prédio está em construção); a Igreja Assembleia de Deus; e a Igreja Adventista do Sétimo Dia (ZAGALLO, 2004; DIAGONAL, 2005).

Em 2004, em se tratando de cobertura vegetal, Cajueiro era constituído de vegetação característica de "mata de capoeira”, que na conceituação de Velho (1972, p. 105) é a "vegetação que cresce depois da queimada”, em função da técnica de agricultura, característica de pequenos agricultores; essa mata de capoeira abrigava um

6. Segundo depoimento de Pai Euclides, líder espiritual da Casa Fanti Ashanti, um dos terreiros de culto afro-brasileiro mais respeitados em São Luís, “A fundadora desse Terreiro [Egito] chamava-se Massinocô Alapong, ela veio como escrava, né, não se sabe se ela foi ou não liberta, a gente imagina que ela veio foragida, né, e aportou ali [..] Primeiro ela morou no Parnauaçu, aí ela passeando por ali naquela redondeza toda, ela admirou muito aquele alto e a gente não sabe até hoje porque ela colocou o nome de Egito lá no morro, isso aconteceu essa fundação lá em 1864" (GEDMMA, 2014, p. 5).

7. Camboa - armadilha de pesca de origem indígena. Trata-se de um círculo de pedra que retém os peixes com a vazante da maré. É encontrada ao longo da faixa litorânea da Ilha de São Luís (GOMES, 2004). Neste caso, trata-se de um bairro do município de São Luís.

8. Sra. Dora, moradora de Cajueiro. Entrevista concedida ao autor em 08 jan. 2005. 
significativo babaçual (que é manejado pelos moradores) de onde coleta-se o coco, cujas amêndoas são beneficiadas para uso culinário ou comercialização. Além da mata de capoeira, a área apresenta ecossistemas marinhos como a praia do Parnuaçu e o Igarapé do Cajueiro, e ainda uma extensa área de manguezal, local de pesca para muitos moradores e de reprodução de aves silvestres. Dos manguezais extraem-se madeira, lenha - produtos já limitados e sob a fiscalização do Instituto Brasileiro do Meio Ambiente e dos Recursos Naturais Renováveis (Ibama) (MENDONÇA, 2006).

Os velhos moradores trazem em suas memórias um tempo de fartura, se referindo ao passado do Cajueiro, ao "tempo de dantes" (NASCIMENTO, 1995, p. 8), que é caracterizado pela abundância de recursos naturais, pela cooperação e troca de dias no trabalho e uma certa estrutura de mercado que absorvia a produção local, como é o caso do manejo do coco e da palha do babaçu, conforme lembra a Sra. Dora:

Coco perdeu mais... porque dantes a gente quebrava, levava pras fábricas ensacado, nós quebrava coco aqui, metia cinco saca de coco; outros já dizia: vamos fazer uma quebra hoje, outra amanhã, outra depois, reunia aquele bando de mulher, quebrava pra uma, depois pra outra, depois pra outra, assim às vezes levava era de dez sacas pra lá, pra cidade. Hoje terminou essas coisas aqui, mas se quebra de vez em quando, faz um azeite, um óleo... assim, não ficou mais como era. Mas os homens trabalham com palha, tirando palha, vendendo pra um e outro, e as mulheres é assim: quem sabe costurar, costura; quem quebra coco pra vender, quebra; mas mais pouco do que era, porque dantes era de saca, ensacado, e agora não, mas dá pra viver... muito servicinho tem aqui pra mulher, aí cria galinha, cria porco... e os homens pescando... (informação verbal) ${ }^{9}$

Além dessas atividades, os moradores de Cajueiro mantinham trânsito permanente com outros lugares, tanto com a área mais urbana de São Luís quanto com outros municípios do interior do estado. Essas características desmistificam a ideia de que as comunidades localizadas na zona rural de São Luís são isoladas, ou que as relações mantidas entre elas e as áreas mais urbanas são de total dependência. Os casos do sr. Aparecido, do sr. João e do jovem Mariano serão tomados para dar início à argumentação de que a chamada área rural de São Luís tem potencial de produção capaz não só de conviver com uma relativa sustentabilidade dos recursos naturais, como também de interagir com o município de São Luís, de forma mais ampla.

0 sr. Aparecido reside no Cajueiro há 57 anos; desde cedo aprendeu o ofício do "pai de criação”, que era pescador. É um exímio conhecedor das práticas de pesca, sabe qual a melhor maré para “arrastar camarão", para pescar embarcado, ${ }^{10}$ da mesma forma que conhece bem as fases da lua - o que lhe garante uma relação privilegiada com os recursos naturais ao saber, por exemplo, quando o camarão está "graúdo". Todo o excedente de peixe e camarão é negociado no interior do estado. Ao retornar, ele traz farinha, arroz, feijão, sabão e ainda algum dinheiro, isso tudo fruto das transações comerciais que podem ser feitas tanto pela "permuta em espécie” quanto pela "permuta monetá-

9. Dora. Entrevista concedida ao autor em 08 jan. 2005.

10. Pesca feita em águas mais profundas que exige a utilização de barcos, às vezes motorizados. 
ria” (BOURDIEU, 1979). 0 sr. Aparecido descreve como faz o escoamento da produção, seguindo uma cadeia de comercialização por meio da qual estabelece relações, em outras localidades, para dar vazão ao excedente de produção (para falar nos códigos da sociedade urbano-industrial):

Cheguei aqui um dia eu botei quarenta e poucos quilos, cheguei em Miranda: "camarão, camarão", aí eu vendi, eu sei que eu vendi ligeiro. Aí comecei a vender pra Miranda, chegava lá trazia uma farinha, aí um cara me disse: "rapaz, sabe onde tu vende bem um camarão? Em São Mateus”. Aí comecei trabalhar lá, trabalhar... Aí lá um rapaz: "rapaz, camarão é bom em Coroatá, em Coroatá que camarão é bom”. Aí eu, Coroatá, e já vim. E lá em Coroatá me disseram que camarão é bom em Codó. E quando cheguei lá, eu sozinho mesmo, arrumei logo uma pessoa pra vender comigo, aí trabalhava um dia, eu via que era um pai de família, aí ele perguntava: "rapaz, tu vai dormir aonde? Dorme lá em casa". Aí ele me dava o agasalho dele e eu fui trabalhando, trabalhando. Ai fui para Pedreiras, depois Bacabal; por aí tudo eu ando e vendo bem, troco também. (informação verbal) ${ }^{11}$

Na prática, o sr. Aparecido está “ampliando seu negócio”, buscando fugir de preços muito baixos praticados na capital. Assim, mesmo sem incentivo e estrutura, desenvolveu a estratégia de buscar "novos mercados” (com potencial consumidor disposto a pagar preços que Aparecido julga mais justo) para os produtos que retira diretamente da natureza, e é essa atividade o seu meio de vida.
Outro morador entrevistado, o sr. João, possui uma área de aproximadamente sete hectares e mantém três tanques de criação de peixes. Sua produção é comercializada, principalmente, na feira do bairro Anjo da Guarda, já na zona mais urbanizada. João diz:

Eu crio em tanques separados porque assim posso ter peixes de várias idades, e trimestralmente abasteço a feira do Anjo da Guarda, mas durante o ano todo eu sempre tenho peixe pronto para o consumo (informação verbal). ${ }^{12}$

Já Mariano, um jovem que tem residência no bairro da Liberdade, passa a maior parte do tempo na praia do Parnuaçu, onde seus pais trabalham por semanas, meses, sem poder ir à casa onde moram seus filhos. Ele relata que fez a opção pelas atividades da pesca como o pai, que é pescador e tem uma casa de palha no terreno cedido por um antigo morador que também é pescador e comerciante dos produtos da pesca. Em geral, notam-se relações de vizinhança entremeadas por relações de parceria nos trabalhos pesqueiros, o que possibilita o engajamento de jovens que não conseguem obter emprego formal no meio urbano. Dessa forma, a pesca torna-se uma possibilidade.

Para Mariano, a comunidade Cajueiro é o local de trabalho da família. Mariano acompanha seus pais para ajudar na manutenção do "meio de vida" da família. Ele tem mais cinco irmãos e todo o provimento da casa é feito com a atividade de pescas do pai. Mariano mostra como é a rotina do trabalho de pesca e a relação com os irmãos mais novos: 
Eu passo mais tempo aqui com meu pai do que em casa, preciso ajudar na pescaria porque é da pesca que a gente tira o sustento da família todinha. Lá em casa são 5 irmãos, aí tem que dar conta de toda a despesa, então nós trabalhamos aqui. Hoje mesmo eu vou levar esses $7 \mathrm{~kg}$ de camarão pra vender e comprar as coisas que tiver precisando lá. (informação verbal) ${ }^{13}$.

Nesse caso, para se manter no modo de vida do bairro da Liberdade, característico dos centros urbanos, é necessário acionar diretamente os recursos naturais. Percebe-se que o ideal de morar na cidade não significa depender dela; há uma dependência vital dos recursos da pesca oriundos do trabalho em Cajueiro, e que não se faz por meio da compra.

Além desses três casos postos à luz, os demais interlocutores de um longo processo investigativo mencionam que fazem plantio de macaxeira, mandioca para produção de farinha e feijão, além de extrativismo da juçara e cultivo de pomar, e seus produtos são comercializados nos mercados em outros bairros, principalmente no Anjo da Guarda.

Foi por conta desse cenário, em que se enredavam diversos meios e modos de vida, que apareceram formas diversas de relações com os "agentes naturais" (flora, fauna, igarapé, mangue) e outras tantas com os “agentes sociais" (moradores, entidades da sociedade civil, poder público) que pretendiam nos fazer crer que o lugar e o modo de vida de seus moradores teriam a "vocação natural" para abrigar três gigantescas usinas siderúrgicas.

Segundo o Decreto Estadual $n^{\circ} 20.727,{ }^{14}$ de 23 de agosto de 2004, o Cajueiro se lo- caliza no município de São Luís, e faz parte de uma extensa área geográfica constituída por outras 10 comunidades, indo desde o Porto do Itaqui (na Baia de São Marcos) até o Rio dos Cachorros:

Módulo D - ZI - 3 e ZR - 10, da Lei Orgânica $n^{\circ} 3.253$ de 29/12/1992, área de implantação do Consórcio ALUMAR com os seguintes limites e configurações: Norte - Riacho dos Cachorros; Leste - BR-135 São Luís Teresina, Estrada de Ferro EFN e CVRD; Sul - Igarapé do Cajueiro e Terras do Coqueiro e Estiva da Gleba Tibiri-Pedrinhas; Oeste Estreito dos Coqueiros (Decreto Estadual $n^{\circ}$ 20.727/2004).

Conforme Zagallo (2004, p. 15), a área pretendida para a implantação do polo siderúrgico constitui uma vasta região, que vai desde o Porto do Itaqui (na Baia de São Marcos) até o Rio dos Cachorros, e que tem aproximadamente $2.471,71$ hectares, abrangendo 11 localidades, quais sejam Bom Jesus do Cajual, Vila Maranhão, Cajueiro, Rio dos Cachorros, Taim, Porto Grande, Ananadiba, Collier, São Benedito, Madureira e Camboa do Frades, com uma população de 14.380 habitantes. A descrição de Zagallo indica que o Cajueiro estava incluso na área requerida para a instalação do polo siderúrgico em São Luís.

Vejamos o que Zagallo (2004, p. 5) escreveu sobre o processo e as características do empreendimento:

A Companhia Vale do Rio Doce, o Governo do Estado do Maranhão e a Prefeitura de São Luís anunciaram a pretensão de instalar um Polo Siderúrgico composto por 3 usinas side-

13. Mariano, jovem morador do bairro da Liberdade. Entrevista concedida ao autor em 25 mar. 2006.

14. Este expediente legal do Executivo Maranhense "Reformula a área do Distrito Industrial de São Luís - DISAL". 
rúrgicas com capacidade de produção de 7,5 milhões de toneladas anuais de placas de aço na Ilha de São Luís, voltadas à exportação, totalizando 22,5 milhões de toneladas/ano, e duas gusarias, em uma área de 2.471,71 hectares localizada na Ilha de São Luís, próximo ao Porto do Itaqui.

Para que se tenha uma idéia da magnitude do empreendimento, basta observar que a produção de aço do Brasil em 2003 foi de 31 milhões de toneladas (em 12 companhias siderúrgicas construídas durante mais de 50 anos) e a produção mundial foi de 965 milhões de toneladas. Assim, a produção pretendida equivaleria a $72 \%$ da produção brasileira e 2,3\% da produção mundial de 2003.

As usinas siderúrgicas que se instalariam no Polo Siderúrgico seriam a chinesa Baosteel (com previsão de futura participação acionária minoritária da francesa Arcelor - maior siderúrgica mundial), a sulcoreana Posco e a alemã ThyssenKrupp, respectivamente a $5^{a}, 1^{\text {a }}, 6^{\text {a }}$ e $9^{\text {a }}$ maiores siderúrgicas do mundo, sendo que o processo de produção de cada uma das usinas utilizaria coque (carvão mineral beneficiado) a ser importado por um novo Porto a ser construído na altura do extremo setentrional da Ilha de Tauá-Mirim.

Ao saberem da iminente possibilidade de deslocamento compulsório para instalação das usinas siderúrgicas, cada uma das comunidades ameaçadas passou a resistir à sua maneira. A reação dos moradores foi imediata e, como não poderia ser diferente, mais do que buscar entender o que seria aquele projeto de fabricação de aço, eles procuraram saber como a efetivação das instalações siderúrgicas iria interferir em suas vidas.

Em Cajueiro, os diretores da União dos Moradores Proteção de Jesus do Cajueiro, em diversas reuniões, manifestaram-se contrários ao deslocamento anunciado pela empresa Diagonal Urbana, alegando que os moradores não teriam outro lugar para ir e que não seriam beneficiados, diretamente, com a construção do empreendimento. Por essa razão, buscaram apoio de outras entidades da sociedade civil para resistirem a uma possível ação de deslocamento.

A Sra. Estela, uma das diretoras da União dos Moradores Proteção de Jesus do Cajueiro, em nossas primeiras visitas, afırmava que:

Se nós sairmos daqui, vamos pra onde? Esse pessoal aqui não tem estudo, não tá preparado para esses empregos dessa empresa que quer vir para cá. Nós estamos acostumados a fazer uma roça, quebrar um coco, pescar ou arrastar camarão. Se a gente sair daqui pra cidade de que nós vamos viver? Da indenizaçãozinha que mal vai dar pra comprar uma casa num bairro desses aí? (informação verbal) ${ }^{15}$.

O Sr. Bruno, outro diretor da União dos Moradores Proteção de Jesus do Cajueiro, também depõe a favor da permanência dos moradores ao afirmar que:

0 povo tem uma identidade, história, religião, alteridade. Tiram o sustento da terra, da lavra, da pesca, das frutas, da coleta... Esses empregos que dizem que vão gerar não é pro

15. Relato colhido na reunião União dos Moradores Proteção de Jesus do Cajueiro, em 31 out. 2004. 
povo do Cajueiro. Só pra ter uma ideia, daqui do Cajueiro só duas pessoas trabalham no porto do Itaqui, e de serviço braçal (informação verbal) ${ }^{16}$.

Tanto a Sra. Estela como o Sr. Bruno rememoram outros projetos instalados no Distrito Industrial de São Luís com a promessa de gerar empregos e melhores condições de vida para a população do seu entorno, e suas declarações mostram o quanto estão desacreditados desses resultados e preferem apostar naquilo que conhecem e sobre o que têm o mínimo de controle, que são os processos de produção local, vinculados ao cultivo da terra, à pesca, ao extrativismo e ao uso de outros recursos naturais.

Compartilhando dessa ideia, o Sr. Osvaldo se opõe às investidas no sentido de construção de indústrias nas terras do Cajueiro, tendo em vista o que segue no depoimento:

Moro no Cajueiro há 26 anos, quando cheguei aqui não tinha escola para essas crianças, então eu e minha esposa, que era professora, resolvemos fazer uma sala, era de taipa. [...] Agora a escola é de tijolo, tem quatro salas e atende crianças do jardim à quarta série... Eu não acho justo que esse povo todo fique sem lugar para morar e tenha que recomeçar tudo (informação verbal) ${ }^{17}$.

As pequenas conquistas dos moradores, frente às relações clientelistas com políticos que ocupam cargos eletivos, como é o caso da Escola Manuela Varela, servem de motivos suficientes para que parte deles não queira deixar o lugar em que moram para novamente ter que reiniciar as peregrina- ções junto aos ocupantes de cargo público, que, não raro, atendem às reivindicações dos moradores desde que estes se tornem, no mínimo, eleitores fiéis. Essa relação da comunidade com políticos que se aproveitaram, e se aproveitam, das necessidades mínimas de infraestrutura da comunidade pode ser observada no documento da Diagonal (2005, p.5):

Em 1986, é fundada a União de Moradores Proteção de Jesus do Cajueiro, por meio de eleição de seus representantes. A idéia da fundação era a obtenção de merenda escolar para os alunos da escola, o que só seria conseguido mediante representação legal. A sede da União de Moradores passa a servir de escola quando se torna necessária a ampliação da antiga Escola Comunitária Costa Ferreira, o que é obtido graças aos contatos da Sra. Alderina, principalmente com a vereadora Lia Varella. Dessa maneira, no mesmo ano de 1986, é concluída a reforma a antiga Escola Comunitária Costa Ferreira passando a se denominar, aí em diante, de Manuela Varella, em homenagem à tia da vereadora.

Como as relações clientelistas não resolvem, de fato, qualquer demanda social, seja ela na área da educação, da saúde, da moradia, do transporte, a precária infraestrutura da comunidade Cajueiro fez com que muitos moradores (fora os poucos beneficiados diretamente pelas ações clientelistas) estivessem o tempo todo, se não buscando, desejando sair do lugar em que vivem. No entanto, as opiniões oscilam de acordo com a posição social de cada morador: tem morador que é pescador/lavrador, vive e depende diretamente dos recursos naturais locais; 
outros são pequenos comerciantes; outros, apenas donos de terrenos na comunidade, mas com residência noutro local, e acesso a outras fontes de recursos materiais. É o caso do senhor Arimateia, que afirma:

Aqui é um lugar distante, não tem ônibus regular e as crianças, quando chegam na $4^{a}$ série, têm que parar os estudos porque as escolas de $1^{\circ}$ e $2^{\circ}$ grau ficam distantes. Além disso, a terra aqui tá cansada, já não dá mais como antes, mesmo o camarão e o peixe são difíceis, dão muito pouco... Seria melhor ter outro lugar pra esse povo morar, mais perto do centro, perto das escolas e de feiras (informação verbal) ${ }^{18}$.

Dependendo da posição social de cada morador, pode-se perceber sua disposição quanto à opção de deixar o território ou permanecer nele, opção esta que pode oscilar entre essas duas hipóteses.

Conforme o jovem Ulisses, morador do bairro Anjo da Guarda que tem um terreno no Cajueiro, a implantação do empreendimento seria de grande importância, e ele aguardaria sua efetivação com expectativa, ao afirmar que:

0 que nós precisamos é escola boa, para preparar essa gente para os empregos que vem. Eu mesmo já tô estudando, me matriculei no SENAI e tô fazendo um curso técnico. Eu tô me preparando para os empregos, mas quem não tiver preparado não vai conseguir nada $\mathrm{e}$ ainda vai perder a casa (informação verbal) ${ }^{19}$.
Esses dois depoimentos, principalmente o último, revelavam a noção de déficit educacional voltado para a preparação de operários para a indústria, e a fé em uma educação tecnológica como sendo a que vai resolver as necessidades dos moradores. Naqueles relatos, em nenhum momento se ouviu falar em educação voltada para a utilização dos recursos naturais de modo a inibir a exploração da natureza, gerando um equilíbrio entre os recursos naturais e as necessidades humanas. É como se a Ilha do Maranhão estivesse marcada para ser uma grande produtora de aço e todos os seus moradores devessem já estar preparados para essa sua "vocação natural”.

A União dos Moradores Proteção de Jesus do Cajueiro promoveu diversas reuniões com os moradores para debater o tema da siderurgia. Em uma das reuniões organizadas, em 31 de outubro de 2004, as lideranças locais que mantinham relações com representantes do movimento social organizado convidaram o sociólogo e advogado Marcelo Barros, e o representante do "Comitê de Defesa da Ilha”, ${ }^{20}$ o advogado Josemar Pinheiro. Ambos se posicionaram contrariamente à implantação do polo siderúrgico e incentivaram os moradores a resistirem.

Josemar Pinheiro, fazendo memória ao movimento que se opunha à implantação da Alumar (Consórcio de Alumínio do Maranhão) e da Companhia Vale do Rio Doce (CVRD), em sua fala corroborou as ideias anteriores, dizendo que:

18. Arimateia, morador de Cajueiro, em entrevista concedida ao autor em 31 out. 2004.

19. Relato colhido na reunião da União dos Moradores Proteção de Jesus do Cajueiro, em 31 out. 2004.

20. 0 "Comitê de Defesa da Ilha" foi um movimento de resistência articulado por ocasião da instalação da Alumar e da CVRD, na década de 1970, na Ilha do Maranhão. Esse comitê tinha como principal objetivo parar a implantação daquelas plantas industriais na zona rural de São Luís. Seu principal representante, à época, era o poeta maranhense Nascimento de Morais, que ficou conhecido no estado como um ambientalista aguerrido (informações disponibilizadas pelo Comitê de Defesa da Ilha). 
A instalação da Vale e da Alumar no interior da Ilha, no final da década de 1970, foi catastrófica. Muitas famílias perderam suas casas e as terras que cultivavam, foram expulsas e se abrigaram nos bairros da periferia sendo vítimas de falta de infraestrutura mínima, desemprego e preconceito; além dos impactos ambientais que até hoje atinge a capital. É necessário, nesse momento, união e pensamento majoritário para que consigamos enfrentar o inimigo. Temos que ir para disputa de poder, para discussão... (informação verbal) ${ }^{21}$.

Frente às ameaças de serem retirados de suas casas, e já conhecendo histórias de pessoas que passaram pela mesma situação quando da instalação da CVRD e da Alumar, os moradores buscaram fortalecer sua resistência ampliando relações com várias entidades da sociedade civil, como o Fórum Carajás, o Movimento Reage São Luís, ${ }^{22}$ e mesmo instituições do poder público, como o Ibama, que estava trabalhando a viabilidade de implantação da Reserva Extrativista (Resex) do Taim - depois renomeada para Tauá-Mirim,$-^{23}$ sobrepondo a área em que se postulava a implantação do polo.

A destinação de mais de mil hectares para a Resex de Tauá-Mirim, que fica localizada na mesma área requerida para sediar o empreendimento siderúrgico, serviu como freio e ajudou nas negociações que levaram à redução da área que seria destinada ao polo. Como vimos, foram requeridos 2.471,71 ha, mas a Lei Municipal $\mathrm{n}^{\circ} 4.548$ de 09 de dezembro de 2005, que altera a Lei $\mathrm{n}^{\circ} 3.253$ de 29 de dezembro de 1992 - que dispõe sobre o zoneamento, o uso e a ocupação do solo urbano -, dentre outras providências criou a zona ZI3 (Itaqui), com área total de 1.063,6088 ha. Portanto, daquilo que pretendiam a prefeitura, o governo do estado e a Vale, houve uma significativa redução da área disponibilizada para a atividade industrial, se compararmos ao que vinha sendo reivindicado.

À época, o temido polo não se efetivou e a mudança legal do território de rural para industrial ficou pela metade, o que de certo modo foi uma vitória das comunidades. Mas o processo continuou.

\section{Cajueiro revisitado: do polo ao porto ${ }^{24}$}

Como vimos, desde a década de 1980 a comunidade Cajueiro sofre tentativas de expulsão. No ano de 1987, o governo federal, pela ação do Conselho de Não Ferrosos e de Siderurgia (Consider), ${ }^{25}$ determinou que o estado do Maranhão apresentasse o projeto de "uma usina siderúrgica integrada, com capacidade de 3 milhões de toneladas ao ano, através da resolução no 199/87 de 08.04.87" (GISTELINCK, 1988, p. 109). Empreendimento que, assim como o polo

21. Relato colhido na reunião da União dos Moradores Proteção de Jesus do Cajueiro, 31.10.2004.

22. 0 "Movimento Reage São Luís" foi uma organização de diversas entidades da sociedade civil e de comunidades diretamente afetadas pelo projeto de instalação do polo siderúrgico em São Luís. Esse movimento foi estudado no trabalho de tese do Prof. Dr. Elio Pantoja, do Desoc/UFMA (ALVES, 2014).

23. As reservas extrativistas são unidades de conservação pelas quais tem-se buscado, ao longo dos anos, uma nova maneira de construir o desenvolvimento sustentado nas comunidades extrativistas. Nessa modalidade de unidade de conservação, prevista pela Lei no 9.985 de 18 de julho de 2000, o ser humano é reconhecido como ator e gestor da conservação (IBAMA, 2006, p. 8).

24. Item inspirado no relatório socioantropológico do GEDMMA (2014).

25. Conselho Federal presidido pelo então Ministro de Estado da Indústria e Comércio. 
siderúrgico, não se consolidaria, mas que também previu o deslocamento de várias comunidades para sua instalação e interferiu diretamente na vida das comunidades. Importante ressaltar que estudos e sondagens técnicas nas duas oportunidades foram realizados.

0 decênio que separa o polo do porto testemunhou inúmeras investidas governamentais e privadas contra os territórios tradicionais das comunidades: deslocamento de 86 famílias da comunidade Vila Madureira com isolamento da comunidade Camboa dos Frades e criação e uso de faixa de domínio para linhas de transmissão em diversas comunidades, quando da construção da termelétrica Porto Itaqui da MPX/Eneva (NOGUEIRA, 2010); duplicação do ramal da BR-135 que liga Pedrinhas ao Porto do Itaqui pela Vila Maranhão; duplicação de vários trechos da ferrovia Carajás, operada pela Vale; especulação de construção do porto da Suzano Papel e Celulose na comunidade Cajueiro (GEDMMA, 2014); especulação de construção de infraestruturas para refinaria premium da Petrobras, do terminal de tancagem em Cajueiro e da dutovia que passaria pela metade das comunidades rurais da parte sudoeste de São Luís (FSADU/UFMA, 2009); ampliação do complexo portuário de São Luís com mais pescadores afetados; ampliação da fábrica da Alumar; construção da fábrica de cimento da Votorantim, em Rio dos Cachorros; construção de pelo menos três fábricas de fertilizantes; utilização de grandes terrenos para arma- zenamento de contêineres; adensamento urbano da área rural com a construção de milhares de unidades residenciais do programa Minha Casa Minha Vida, sem nenhum estudo dos impactos às comunidades rurais e aos sistemas ecológicos.

A história se repete!? Duas coisas perduram: a ausência proposital das mais diversas políticas estatais somada às investidas do capital industrial e especulativo de um lado e, do outro, a resistência das comunidades, sobretudo na luta pelo reconhecimento dos seus territórios de pesca, lavoura, extrativismo e moradia - entre outras ações, a luta pela criação da Reserva Extrativista de Tauá-Mirim é uma das formas de sua garantia territorial.

Em 2014, mais uma vez com o apoio dos governos municipais e estaduais, outra empresa, a WPR - São Luís Gestão de Portos e Terminais Ltda. ${ }^{26}$, cobiça o território das comunidades e, utilizando-se de violência brutal, ameaça e destrói casas dos moradores do Cajueiro.

Pesquisadores do grupo de estudos GEDMMA acompanharam todo o processo, estando presentes em várias reuniões da comunidade do Cajueiro no ano de 2014; participaram inclusive da ação do dia 15 de outubro, uma ação dos moradores de diversas comunidades que paralisou o trânsito da BR-135 na altura da entrada do Cajueiro, e da tentativa de realização de uma audiência pública, no dia 16 de outubro, que trataria do licenciamento da instalação do Terminal Portuário de São Luís pela refe-

26. A WPR - São Luís Gestão de Portos e Terminais Ltda., empresa responsável pela suposta construção do Terminal Portuário de São Luís, afirma no seu Estudo de Impacto Ambiental (EIA) que foi realizada "compensação social", sendo a "Urbaniza Engenharia Consultiva, empresa responsável pela gestão fundiária de desapropriação e indenização da poligonal de implantação do empreendimento” (MRS, 2014). Isso atesta que a empreendedora fez as vezes do Estado ao contratar uma empresa responsável em realizar a "gestão fundiária de desapropriação e indenização” - ao que tudo indica, com a conivência dos órgãos estatais. 
rida empresa WPR, impedida pelos moradores que alegavam razões tais como: a empresa estaria utilizando milícia armada para intimidá-los, além de coagi-los a vender suas posses à empresa. Os moradores também questionavam o descumprimento de prazos legais para convocação da audiência e a indisponibilidade para consulta pública do EIA-RIMA (GEDMMA, 2014).

Uma série de dispositivos de poder foram acionados para potencializar o clima de insegurança jurídica e medo entre os moradores em relação ao destino do seu território, o que favoreceu negociações não desejadas e sem a avaliação adequada por parte deles. Pode-se elencar a presença de seguranças armados na localidade (cerca de 20) vinculados à empresa de segurança Leões Dourados, cujo trabalho foi posteriormente identificado pela Polícia Federal como irregular e, portanto, constituía-se uma milícia privada.

Uma breve análise das reuniões organizadas pelos moradores naquele ano, 2014, permite evidenciar o caráter violento e ilegal do processo de negociação da empresa para com moradores das comunidades. $\mathrm{Na}$ reunião realizada no Andirobal (Cajueiro), que contou com a participação da Comissão Pastoral da Terra (CPT), de pesquisadores da Universidade Federal do Maranhão (UFMA), de assessores do Gabinete do Deputado Estadual Bira do Pindaré e de cerca de 30 moradores da comunidade, foram realizadas diversas denúncias graves acerca da violência do processo em questão. Seguem trechos da reunião:

Morador: [...] se você quer construir na sua área, eles não querem deixar entrar mate- rial. Eu acho isso errado porque se você não vendeu a sua área você tem direito de trabalhar na sua área e eles não querem deixar você trabalhar, fazer sua casa e tal. Isso aí eu acho errado, né? Porque se você já vendeu sua área eles têm direito de chegar e mandar, né? Mas como eles ainda não indenizaram, não me indenizaram, eles têm de direito de chegar e mandar pedir, mais e aí?

Senhor Batata (morador): Oh! É assim, semana passada teve um problema seríssimo aí, né! A gente morando aqui, né! E de imediato a gente soube que eles estavam botando dois postes. [...] Já tinham me falado que eles iam botar essa corrente lá no Anjo da Guarda. Aí eu fiquei com a orelha em pé, né! Corrente, é... Vão botar corrente pra não passar. E o que aconteceu foi isso mesmo. No outro dia, eles vieram e enfiaram os dois tubos, um dum lado outro doutro, e ainda cavaram um buraco impedindo, tapando a rua do pessoal que mora na esquina do colégio, hem! Aí, de repente, o filho da minha irmã chegou aqui e disse "Zé, tem um movimento lá na portaria do colégio, porque abriram uma vala lá e tão... e vão botar a corrente". Aí eu fiquei assim meio rabolado, aí pegamos o carro, aí descemos pra lá. Quando chegamos lá, tava esse movimento lá. 0 cidadão lá, o grandão que deve ser o chefe, né? Num sei! Com um rádio na mão e botando marra no pessoal, né! Dando pressão, né! Aí eu cheguei, já tava o presidente e a vice-presidente. ${ }^{27}$ Aí, eu cheguei e vi aquele movimento, né! Aí, a gente deu pressão pra tirar um dos postes, né! 0 mais fino. 0 pessoal que já tava lá chegaram, os meninos chegaram e tiraram um. Só que o outro tava muito enterrado, né! Aí o cara chegou e botou a mão, o guarda, né! 0 "paideguão" que tava com o rádio na mão (informação verbal ${ }^{28}$.

27. 0 morador refere-se ao presidente e à vice-presidente da União de Moradores do Bom Jesus do Cajueiro. 28. Relatos extraídos da reunião realizada no Andirobal - Cajueiro, 2014. 
A chegada desse novo empreendimento vem cerceando direitos dos moradores, como elencado acima, tentando colocar estacas e obstruir com corrente a passagem. A facilidade com que essas ações irregulares foram executadas em Cajueiro deve-se à memória dos moradores das possibilidades de deslocamento, ocorridas no passado recente, e à forma de atuação da empresa que mesclou ritos estatais e privados, não deixando clara a natureza privada das ações, e usando de extrema violência.

Mas o sentimento de permanecer nas terras que compõem a gleba do Cajueiro, como forma de reprodução material e cultural do grupo, continua presente na população. Através da "memória viva”, os moradores acionam traços, histórias, relatos que estabelecem a fronteira entre aqueles que "nasceram e se criaram" lá, em contraposição aos “de fora” ${ }^{29}$ cujo deslocamento não pesaria, na maioria dos casos, no processo de negociação das terras. Pode-se perceber isso no trecho seguinte da reunião na União dos Moradores do Cajueiro:

Participante 1: Seu... Nem todo mundo quer sair do Cajueiro, mas cinquenta por cento (50\%) quer sair daqui. Eu tô errado?

Participante 2: (em voz alta): Quem quer sair? Quem é que tá aqui que quer sair? Levanta o braço quem quer sair (poucos levantaram).
Participante 2: (em voz alta) Agora levanta o braço quem quer ficar.

Outros participantes: Eu...

Participante 3: Cinquenta por cento (50\%) são pessoas que vêm lá de fora.

Participante 4: Alguém daqui gravou um vídeo dizendo que queria sair daqui?

Participantes: Não...

Participante 4: Porque a... tá dizendo que a empresa tem. (informação verbal) ${ }^{30}$

As populações tradicionais, além de enfrentarem ao longo de décadas as investidas estatais e empresariais no sentido de expropriar seu território em favor da construção de indústrias, também enfrentam as investidas desses especuladores, ${ }^{31}$ que têm posto em dúvida a identidade das comunidades tradicionais e difıcultado a efetivação da proposta de criação da Resex de Tauá-Mirim.

Outra vez mais, social e ambientalmente injustiçada, a comunidade Cajueiro encontra-se em meio a uma ferrenha disputa territorial, cujos extremos são a empresa WPR São Luís Gestão de Portos e Terminais Ltda. e o estado do Maranhão com seu aparato jurídico-legal mobilizado para atender às demandas mais expansivas de um ambicioso projeto de incremento de infraestrutura logística na Baía de São Marcos, sem qualquer possibilidade de inclusão das comunidades tradicionais nos planos de negócios.

29. Nos últimos anos, entre outros fatores, devido aos deslocamentos realizados em outras comunidades ou às expectativas de obtenção de indenizações de empreendimentos estatais ou privados, houve significativo estabelecimento de novos moradores ou posses de terrenos em algumas comunidades localizadas na Zona Rural II de São Luís. Isso faz com que moradores que residem na área há mais tempo (algumas famílias estão ali secularmente) façam a diferenciação entre os moradores "que nasceram e se criaram" na região e os "de fora".

30. Relatos extraídos de reunião da União dos Moradores do Cajueiro, em 17 out. 2014.

31. Mendonça (2006) destaca que até aquele ano a comunidade Cajueiro possuía cerca de 183 famílias, com o processo de intensa especulação da terra; atualmente considera-se a existência de 600 famílias (MRS, 2014), ou seja, em pouco menos de uma década triplicou o número de famílias, muitas das quais mantêm apenas os terrenos cercados sem qualquer exercício de posse, numa demonstração inconteste de apropriação especulativa do território. 
0 governo do estado do Maranhão, até o final de 2014, tem se posicionado de forma francamente parcial frente aos conflitos que se desencadeiam entre empresas e comunidades tradicionais ao longo de décadas. Em praticamente todas as situações o estado do Maranhão tem atuado no sentido de criar condições para constranger e deslocar as comunidades, em favor da instalação de empreendimentos industriais ou de infraestrutura, mesmo que estes criem impactos negativos nos âmbitos social, econômico, cultural e ambiental.

De modo geral, as estratégias de grupos empresariais em cooperação com órgãos estatais para garantir lucro e expansão de capital, em desfavor dos grupos e comunidades tradicionais, têm sido muito comuns nas práticas de multinacionais pelo mundo afora, que pilham e expropriam os ativos comuns dos povos. Harvey (2012), ao analisar o processo de "acumulação por espoliação”, demonstra como as grandes corporações têm garantido o controle territorial, para o avanço do capital, a partir do uso do aparato estatal.

Dentre os muitos exemplos citados por Harvey, apresentamos o caso de expropriação dos territórios camponeses nos Estados Unidos, ${ }^{32}$ em favor do agronegócio:

A expulsão de populações rurais ocorrida [...] do longo processo de substituição nos Estados Unidos da agropecuária familiar pelo agronegócio. A principal força motriz dessa transição sempre foi o sistema de crédito, porém talvez o aspecto mais relevante dis- so seja o fato de uma variedade de instituições do Estado, ostensivamente destinadas a proteger a agropecuária familiar, terem desempenhado um papel subversivo ao facilitar a transição que deveriam conter. (HARVEY, 2012, p. 129)

Harvey ainda nos lembra que "toda formação social, ou território, que é inserida ou se insere na lógica do desenvolvimento capitalista tem de passar por amplas mudanças legais, institucionais e estruturais" (HARVEY, 2012, p. 127). Em boa medida, isso é o que vem ocorrendo nos processos de instalação de empreendimentos, nas últimas décadas, na Ilha do Maranhão, que expulsam as comunidades tradicionais em nome de um suposto desenvolvimento, avalizado pelo Estado.

Seria a efetivação da privatização dos ativos e insumos existentes nos territórios das comunidades tradicionais, que passam ao controle do capital em cooperação com órgãos do Estado e que podem eliminar as possibilidades de existências dos seus modos e meios de vida, deslocando-os para áreas urbanas periféricas com sérios déficits estruturais.

Essas investidas de toda ordem contra os territórios dos povos e das populações tradicionais têm sido o que conduz a ação de órgãos do Legislativo, Judiciário e Executivo dos Estados. A ampliação da logística mundial para circulação de ativos de capital tem desconsiderado qualquer direito territorial dos grupos tradicionais. E o que se vê ocorrer com as comunidades rurais de

32. Ao utilizarmos as exemplificações de Harvey (2012) não as tomamos de modo a fazer equivaler as noções de camponês ou agricultura familiar dos contextos brasileiro e estadunidense, mas tão somente para ilustrar como as investidas dos ativos de capital nacional ou internacional utilizam-se, em situações díspares e especificas, de estratégias semelhantes de cooperação empresa-Estado para expropriar os territórios, expulsar as populações e assegurar a rentabilidade dos investimentos financeiros. 
São Luís é uma articulação entre Estado e empresa para fazer parecer legal o processo de expropriação dos territórios das comunidades tradicionais.

A estratégia, no caso da expropriação em tela, foi a criação de uma empresa, sem expressão e sem uma "imagem a zelar", para realizar o "serviço de limpeza do território". Assim, quem aparece na cena pública como empreendedora da instalação do Terminal Portuário de São Luís é a WPR - São Luís Gestão de Portos e Terminais Ltda., uma empresa com raríssimas informações públicas, legalmente representada pelo Sr. José Hagge Pereira, que declara R\$ 10.000,00 (dez mil reais) de capital social, e se responsabiliza pela construção do empreendimento no valor de $\mathrm{R} \$ 800.000 .000,00$ (oitocentos milhões de reais) ${ }^{33}$. Dessa empresa, o Estado nada revela, não se tem nenhuma informação da sua capacidade técnica e financeira de realizar o empreendimento; o que se sabe, pelos relatos dos moradores de Cajueiro e das demais comunidades tradicionais, é que seus representantes estão utilizando de métodos intimidatórios e coercitivos para garantir a retirada das comunidades tradicionais. E, mais uma vez, os órgãos estatais ou se omitem ou colaboram com a atitude violenta da empresa (GEDMMA, 2014).

Sobre os desdobramentos do processo autoritário de instalação do Terminal Portuário de São Luís denunciados pelas comunidades, diversos sítios eletrônicos e periódicos de circulação diária veicularam informações que dão conta de como as co- munidades tradicionais do território rural de São Luís têm reagido às investidas de desapossamento das terras ancestralmente ocupadas.

Do sítio eletrônico do Fórum Carajás, ${ }^{34}$ destaca-se que:

Os moradores, que organizaram uma manifestação no último dia 15 de outubro, voltaram a relatar truculências por parte da WPR, empresa que pretende construir um porto privado em parte do território da comunidade do Cajueiro. Moradores afırmam que a empresa assumiu postura opressora, não apenas contra os líderes do movimento, mas contra todos os moradores que desejam ir até a praia, mangue ou sítio vizinho. De acordo com relatos de uma antiga moradora, a WPR chegou a colocar um portão e placas com 0 intuito de intimidar as pessoas.

“A gente mora aqui há mais de 30 anos, possui o documento comprovando propriedade da terra e eles colocam jagunços para tentar tomar o que é nosso por direito e por lei. É revoltante! Eles querem colocar em nossas cabeças que nós somos os invasores e eles os proprietários”, protestou.

Uma ex-moradora confirma que a empresa prometeu casa, trabalho e, inclusive, tratamento de saúde. No entanto, afirma que após o pagamento e demolição da casa, a empresa não cumpriu os outros pontos do acordo. "Eu tenho problemas de saúde, eles me prometeram tratamento, mas depois que vendi a casa nunca mais retornaram meus contatos. Estou sem dinheiro para

33. Informações contidas no processo de licenciamento do empreendimento Terminal Portuário de São Luis, da WPR - São Luís Gestão de Portos e Terminais Ltda., em trâmite na SEMA.

34. COMUNIDADE Cajueiro questiona como WPR compra terreno de assentamento do ITERMA para construir porto privado em reserva extrativista. Fórum Carajás. Disponivel em: $<\mathrm{http}$ ://www.forumcarajas.org. br>. Acesso em: 02 nov. 2014. 
comprar meus remédios e sem ter onde plantar. Comprei uma casa que não vale o terreno da minha. Eu só vendi porque não tinha mais jeito", revelou.

0 blog do Ed Wilson veiculou a matéria "Na zona rural de São Luís, comunidade do Cajueiro reage às ameaças de empresa WPR" ${ }^{35}$. 0 site da Defensoria Pública do estado, a matéria "Defensoria garante uso da terra e de recursos naturais pela comunidade do Cajueiro" ${ }^{36}$ :

A Defensoria Pública do Estado (DPE), através do Núcleo de Moradia e Defesa Fundiária, conseguiu na Justiça Estadual liminar que determina a abstenção, por parte da empresa WPR São Luís Gestão de Portos, de atos que impeçam a realização de plantações, de construções, do extrativismo e da pesca pela comunidade do Cajueiro, situada na região da Vila Maranhão, na capital.

0 jornal 0 Imparcial, na notícia de capa do dia 15 de outubro de 2014, "População se revolta contra 'jagunços' e interdita a BR-135", afirma que:

De acordo com a pescadora Rosana Mesquita, mais de 30 homens armados, que prestam serviço a empresa WPR (Nelson Segurança), estão há três meses dentro do povoado, coagindo, ameaçando e até agredindo verbalmente os moradores. Segundo ela, a comunidade está sendo impedida de chegar até a praia, nas lavouras de onde tiram o sustento de suas famílias [...] Ainda de acordo com a pescadora, a WPR teria sido enviada para a comunidade a ordens de um consórcio de empresas que estão responsáveis pela construção de um porto naquele local. Ela citou algumas destas empresas como Suzano Papel e Celulose, Petrobras, Cargil Imbunge, entre outras (0 Imparcial, 15 de novembro de 2014).

As tentativas e a execução de negociações de terras com moradores ocorreram sob forte pressão. Várias estratégias para retirar as pessoas de suas terras foram utilizadas. Destaca-se a retórica apresentada aos moradores, segundo a qual aquela seria uma "oportunidade" diante da possibilidade de desapropriação por parte do Estado, uma vez que a área já teria sido destinada à construção do porto.

Uma moradora da praia de Parnuaçu, em Cajueiro, foi insistentemente assediada por representantes da empresa WPR a fim de que vendesse suas terras. Note-se que a referida senhora - Dona Eurídes, de 93 anos vivia na região por quarenta anos com seu marido (pescador), tendo criado seus filhos e netos no local, trabalhando com agricultura e criação de pequenos animais, como galinhas, patos, porcos. Segundo Dona Eurídes, tudo o que precisa está naquele povoado, pois, se precisar comer, vai ao mar e pesca peixes, ou então vai ao quintal e pega galinhas que cria. Ela relatou: "Eu sou muito feliz aqui", ressaltando ainda as relações afetivas e de auxílio mútuo que tem com pessoas mais antigas. Contudo, meses depois, não só a senhora cedera às inves-

35. ARAÚJO, E. W. F. Na zona rural de São Luís, comunidade do Cajueiro reaje às ameaças da empresa wpr. Blogue do Ed Wilson. 28 out. 2014. Disponível em: <http://blogdoedwilson.blogspot.com.br/2014/10/ na-zona-rural-de-sao-luis-comunidade-do.html\#.VFbQZvnF_wg>. Acesso em: 02 nov. 2014.

36. DEFENSORIA garante uso da terra e de recursos naturais pela comunidade do Cajueiro. Defensoria Pública do estado do Maranhão. Disponível em: <http://www.dpe.ma.gov.br/dpema/index.php/SiteInstitucional/ver_noticia/3490>. Acesso em: 02 nov. 2014. 
tidas da empresa, como a área da praia de Parnuaçu já se encontrava interditada, impedindo que os moradores tivessem acesso à pesca, e algumas casas foram demolidas. Uma das ameaças que essa senhora relatou foi a de que os representantes da empresa diziam que, se ela não vendesse a casa, o Estado a tiraria dali forçadamente sem nenhuma indenização (GEDMMA, 2014).

Situação semelhante ocorreu com o senhor Joca, pescador de 77 anos, vindo do município de Alcântara, que vive no Cajueiro há 35 anos, onde criou seus filhos e netos: por várias vezes, Joca teve sua casa demarcada por representantes da empresa como local a ser comprado. Esses representantes foram à sua casa e, de modo suspeito, pediram seus documentos explicando que seria para ele receber um benefício do governo, visando claramente a ludibriá-lo. Ele não entregou os documentos, pelo que passou a ser assediado sistematicamente para que vendesse sua propriedade, vastíssima em produções agrícolas como a de abacaxi. Esse senhor não cedeu e atualmente resiste à expulsão de sua família do local.

Da parte do estado do Maranhão (aqui compreendendo órgãos como secretarias de Estado, empresa portuária, instituto de terras, órgãos da justiça), quando não se fez totalmente omisso, foi o bastião das investidas dessas empresas, desde a década de 1970, quando diversas comunidades, mesmo com muita resistência, viveram a trágica experiência da expulsão dos seus territórios (GISTELINCK, 1988).

Conforme diz Gistelinck (1988, p. 152), os custos sociais desses empreendimentos são colossais: "as raízes culturais estão sendo destruídas: suas relações humanas de parentesco, de compadrio, de comunidade, suas capacidades, profissões, técnicas e aptidões, suas relações com a natureza, com a terra, com Deus”.
Há uma década, uma moradora do Cajueiro já anunciava o pavor às indenizações irrisórias pagas por empresas com o assentimento do Estado. Segundo a Sra. Estela, sua prima foi vítima de indenizações ínfimas quando da implantação do Porto do Itaqui e da então CVDR. Ela lembra que:

[...] nessa situação que a gente ver o que já passaram é que a gente se preocupa... que pode acontecer com a gente, que a gente tá aqui hoje no Cajueiro a gente ainda não passou por isso, a gente tá tranqüila. Então a gente tá preocupado desse dia de amanhã, eles virem tirar nós daqui e nós passar pela situação desses outros que já passaram. [...] uma prima minha, ela recebeu a indenização dela no Itaqui, o que ela fez? Comprou uma casa na Mauro Fecury, no pior lugar do Anjo da Guarda, porque só dava pra comprar lá que era mais barato. Aí foi pra loja comprou uns móveis, depois o dinheiro acabou, agora ela vive urrando... (MENDONÇA, 2006, p. 39).

A deliberada opção estatal em negar a existência das comunidades tradicionais ou, ao reconhecê-las, classificá-las como um mal do passado que precisa ser extirpado, mesmo que para isso sejam levadas à sobrevida nas periferias urbanas mais violentas, tem sido historicamente recorrente e, no caso de São Luís, isso é um processo contínuo.

Vários trabalhos e registros etnográficos do GEDMMA, mais a diversa bibliografia disponível (GISTELINCK, 1988; ANDRADE, 1981; ANDRADE; CORRÊA, 1986, 1987; ADRIANCE, 1996) dão conta de que o estado do Maranhão, no caso da Ilha do Maranhão, especifıcamente na Zona Rural II de São Luís, tem sido conivente com o avanço de um modelo de desenvolvimento econômico que combate toda tentativa de fazer 
as comunidades tradicionais viverem com seus modos e meios de vida próprios, compatíveis aos tempos dos sistemas ecológicos a que pertencem.

No caso atual da comunidade Cajueiro, o governo do estado do Maranhão, impedido judicialmente de deslocar qualquer comunidade na área requerida para a criação da Reserva Extrativista de Tauá-Mirim, preferiu não ver o que ocorria na comunidade Cajueiro por quase seis meses. Segundo relatos dos moradores, ocorreu toda sorte de ameaças, pressões psicológicas e assédios de toda ordem, patrocinados pela empresa WPR - São Luís Gestão de Portos e Terminais Ltda. e suas contratadas para garantir a "limpeza da área", ou seja, a retirada da população que tradicionalmente vive no território.

Dois fatos acompanhados por pesquisadores do grupo GEDMMA chamaram muito a atenção. 0 primeiro refere-se à tentativa de realização da Audiência Pública, convocada pela empresa e que seria presidida pela Secretaria de Estado do Meio Ambiente (Sema), no dia 16 de outubro de 2014, na Escola Gomes de Sousa - Vila Maranhão, impedida pelos moradores que se manifestaram concentrando-se nos portões da escola onde ocorreria tal audiência. Naquela ocasião, quatro moradores acorrentaram-se nas grades de ferro da escola para impedir a realização da audiência porque temiam que a Sema, mesmo contra a vontade da comunidade, após a audiência emitisse a licença de instalação. Na ocasião, numa demonstração de relação simbiótica Estado-empresa, o secretário adjunto da Sema, utilizando-se do som que a comunidade conseguira para denunciar o ocorrido, declarou, literalmente no meio da rua, que a audiência estava oficialmente aberta, numa clarividência de que estava a serviço dos interesses da empresa, desconsiderando todos os apelos e argumentos da comunidade e, sobretudo, as denúncias de que os representantes da empresa estavam, há meses, coagindo e amedrontando os moradores - atitude que não prosperou em razão das enfáticas reações dos moradores ali presentes, fazendo com que o secretário adjunto recuasse do seu intento.

0 fato seguinte foi o desdobramento do ato do secretário adjunto da Sema. A empresa WPR, com a conivência da Sema, marcou nova audiência, dessa vez para o dia 29 de outubro de 2014, quarta-feira, após um final de semana seguido de ponto facultativo e feriado nos dias que antecediam a audiência (dias 27 e 28), nas dependências do Comando Geral da Polícia Militar do Maranhão - audiência literalmente aquartelada, no bairro Calhau, numa incontestada tentativa de intimidar os possíveis participantes. E, embora tenha havido a formalização de pedido de suspensão, a Sema deu continuidade ao escandaloso rito da audiência, com a participação majoritária de moradores de bairros bem distantes de onde seria construído o empreendimento. Situação jamais vista em audiências públicas para licenciamento ambiental acompanhadas ao longo dos anos, tanto em função da súbita motivação de pessoas majoritariamente jovens que residem fora da área de impacto direto do empreendimento - em participar dela, como também pela opção em realizá-la nas dependências do Comando Geral da Polícia Militar.

Em resposta ao aparente relacionamento simbiótico Estado-empresa, as comunidades do território da Resex de Tauá-Mirim, irmanadas com Cajueiro, resolveram não participar da audiência formalmente convocada pela Sema-empresa, porque entendiam que ela serviria somente para legitimar as 
ações do par Estado-empresa. Decidiram, em reunião da União de Moradores, realizar sua própria audiência, que batizaram de “Audiência Popular”. Esta ocorreu na União de Moradores Proteção de Jesus do Cajueiro, na comunidade Cajueiro, no mesmo dia e horário daquela convocada pelo par Sema-empresa, e contou com quase duzentos participantes. $\mathrm{Na}$ ocasião, diversas instituições e representantes de órgãos públicos estiveram presentes em defesa dos direitos das comunidades tradicionais, como a Comissão Pastoral da Terra (CPT), as Irmãs de Notre Dame, o GEDMMA, professores, pesquisadores e estudantes universitários, a Defensoria Pública do Estado (DPE), o Ministério Público Estadual (MPE), a Delegacia de Conflitos Agrários, o deputado estadual Bira do Pindaré (PSB), o representante da vereadora Rose Sales (PV), a Central Sindical e Popular (CSP-Conlutas).

A despeito da luta, e das denúncias públicas aos órgãos dos executivos municipal e estadual e ao poder Judiciário sobre a violenta ação da empresa WPR em Cajueiro, no dia 31 de dezembro de 2014 Arnaldo Melo, então governador, publicou no Diário Oficial do Estado do Maranhão a desapropriação das terras da comunidade Cajueiro em favor da empresa WPR (Decreto $n^{\circ} 30.610$, de 30/12/2104, DOE no 254 de, 31/12/2014). Os efeitos desse decreto foram suspensos pelo governo de Flávio Dino, entretanto nem o governador cancelou o decreto de desapropriação, nem a Sema, a licença prévia concedida à WPR. Como última demonstração de que o Estado, mesmo agora sob o comando de grupo político supostamente distinto do anterior, continua avalizando esse projeto que expulsa a comunidade Cajueiro, no dia 15 de outubro de 2015 a empresa WPR divulgou aviso em jornal de circulação local informando que "requereu a Licença de Instalação" do porto (O ESTADO DO MARANHÃO, 2015).

\section{Último ato: São Luís é Cajueiro, ou seria o desfecho de uma tragédia?}

Como já vimos, não se trata de nenhuma novidade que, desde o final da década de 1970, empresários, setores conservadores e grupos políticos ávidos por poder, dinheiro e terra, muita terra, têm investido contra as comunidades tradicionais, controlando seus cartórios, provocando o Judiciário em todo o estado do Maranhão, sob o pretexto de desenvolver o estado e criar empregos para o povo, sobretudo para a juventude. Como diriam Chico César e Carlos Rennó, "tudo mentira":

Vocês desterram povaréus ao léu que erram, E não empregam tanta gente como pregam. Vocês não matam nem a fome que há na Terra, Nem alimentam tanto a gente como alegam. É o pequeno produtor que nos provê e os Seus deputados não protegem, como dizem: Outra mentira de vocês, Pinóquios veios. Vocês já viram como tá o seu nariz, hem? (RENNÓ, 2015).

Para se ter ideia da gravidade dos conflitos por terra na Ilha do Maranhão, que coincide com uma região metropolitana constituída de quatro municípios, São Luís (capital do estado), São José de Ribamar, Paço do Lumiar e Raposa, um documento da Secretaria de Estado de Segurança Pública dá conta de que, das 183 sentenças judiciais de reintegração de posse emitidas pelo Tribunal de Justiça para todo o estado, até janeiro de 2015, 121 são referentes a litígios na região metropolitana, ou seja, $66 \%$ estão concentradas em apenas quatro municípios, sendo que o estado constitui-se 
de 217, e uma parte significativa envolve particulares que se dizem proprietários requerendo e cobiçando os territórios de posse de comunidades.

Não bastasse isso, como ato final a prefeitura de São Luís iniciou em agosto de 2015 uma série de quinze audiências públicas com a finalidade de consultar a população sobre a revisão do Plano Diretor da Cidade, com alterações da Lei de Zoneamento, Parcelamento, Uso e Ocupação do Solo; recordemo-nos que isto já ocorreu também em 2004, quando parte do território rural das comunidades passou legalmente a área industrial.

Esse processo tem causado muita confusão, informações desencontradas, falta de publicização, e tem gerado diversos conflitos. A mídia local praticamente silenciara, e a prefeitura conduz o processo sem qualquer interesse em dar-lhe ampla visualização. Somente às vésperas das audiências a população teve acesso ao documento oficial "Minuta de anteprojeto de lei: estabelece normas para o zoneamento, parcelamento, uso e ocupação do solo no município de São Luís" - um arquivo com 246 páginas de informações técnicas já muito questionadas por estudiosos, lideranças das comunidades e vários setores da sociedade civil organizada, mas também celebrado pela prefeitura, por algumas secretarias municipais e estaduais e pelo setor empresarial, sobretudo da construção civil e da indústria.

Por que silenciar tanto sobre uma proposta que deveria ser amplamente divulgada? Quais interesses resguardam-se na discrição da proposta? Quais os reais impactos para o povo de São Luís e de toda a região metropolitana? Qual o destino das comunidades rurais?

As mídias alternativas têm debatido e apontado fatos incontestes. 0 jornal Vias de Fato, em sua edição de agosto de 2015, escreveu que:
A gestão do prefeito Edivaldo Holanda Júnior poderá entrar para a história como aquela que piorou a situação de São Luís de maneira dramática e irresponsável. 0 problema (grave!) é a possibilidade real de alteração da Lei de Zoneamento, Uso e Ocupação do Solo e do Plano Diretor da Cidade, a ser encaminhada, após uma controversa e pouco divulgada série de audiências "públicas", para a câmara de vereadores (VIAS DE FATO, ago. 2015, capa).

Ao fazer a cobertura das audiências públicas, nessa mesma edição, o jornal acrescenta que:

“Isso aqui já está atrasado. Estou perdendo dinheiro com essa demora”. A frase, dita por um dos engravatados que no dia 18 de junho assistia a uma prévia do que seriam as audiências públicas para a revisão da Lei de zoneamento, uso e ocupação do solo e do Plano Diretor de São Luís é emblemática da parcela que espera se beneficiar com a alteração dessas importantes leis. [...] Para se ter uma ideia do que está envolvido, essas leis disciplinam praticamente todo o cotidiano da cidade, desde a mobilidade urbana, poluição, dimensão das construções que podem ser feitas ou ampliadas, formas de uso e ocupação das áreas, políticas habitacionais, entre outros temas (VIAS DE FATO, ago. 2015, p. 6).

Talvez com esse serviço público prestado pelo citado jornal possamos ter ideia do que realmente a prefeitura e seus aliados pretendem com tal proposta, que, embora tenha propósitos e objetivos bem definidos para a cidade de São Luís, recebeu quase inexistentes divulgações que propagam-na desinteressada e ingênua. Ou talvez isso nos leve a mais um questionamento: afinal, o que quer esconder a prefeitura de São Luís dos seus cidadãos? 
Seria o fato de que, com o aumento do gabarito $^{37}$, os prédios poderão chegar até 31 andares, o que poderia piorar em muito a mobilidade urbana? 0 aumento da pressão no já combalido sistema de trânsito e de transporte público aumentaria a pressão sobre os já deficientes sistemas de abastecimento de água e coleta e tratamento de esgotos? Ou seria para passar despercebidamente que, com a ampliação de área e do tipo de indústrias, aumentariam também os índices de poluentes, já bem acima dos padrões tolerados pela legislação? $\mathrm{Ou}$ seria ainda para que as comunidades que viessem a perder seus territórios só despertassem quando a lei já estivesse aprovada? Seria tudo isso junto?

Pela proposta da prefeitura, na atual zona rural adjacente ao Porto do Itaqui sobrariam apenas duas comunidades (Taim e Rio dos Cachorros), com a denominação esdrúxula de zona rural mista (ZRM), isoladas, sem qualquer condição de reprodução material e cultural, e premidas pelas emissões de poluentes industriais - é um projeto de morte para as comunidades.

0 jornal Vias de Fato, mais uma vez, dá pistas para essas respostas.

Segundo matéria produzida pelo Instituto da Cidade (INCID) e distribuída para jornais e blogues alinhados à prefeitura de São Luís, um dos objetivos da alteração da legislação é a proteção ambiental. Não é o que se observa, entretanto, na proposta de alteração que pode ser consultada na página da prefeitura na internet: há a previsão de alteração do padrão das construções em várias partes da cidade, que poderão, se aprovada a proposta, passar a constar com prédios de amis de 30 andares, numa extrema concentração populacional em meio ao caos já vivido hoje em várias partes da cidade, especialmente em relação ao trânsito e ao transporte coletivo. Essa é uma demanda clara das construtoras em detrimento da qualidade de vida na cidade.

Outro ponto que demonstra que de proteção ambiental a proposta de revisão do Plano Diretor não tem nada é a alteração no zoneamento da cidade, transformando várias áreas, hoje rurais, nas quais há comunidades centenárias, em industriais, mista ou de retroporto (VIAS DE FATO, ago. 2015, p. 6).

Os altos níveis de poluentes do município de São Luís são denunciados há bastante tempo pelo advogado e estudioso da matéria Guilherme Zagallo. Ele participou de várias reuniões, de encontros e de várias dessas audiências públicas denunciando que a proposta de alteração da lei apresentada pela prefeitura pode levar toda Ilha do Maranhão a um colapso. Em entrevista ao jornal, reafirmou as denúncias:

[...] Depois desses dados divulgados em 2005, tivemos o aumento da operação de exportação de minério da Vale de 70 milhões de toneladas/ano para 130 milhões de toneladas. Até 2019 serão 220 milhões de toneladas de minério de ferro. Na Alumar ocorreu a ampliação da fábrica de alumínio de 1,5 milhão de toneladas/ano para 3,5 milhões de toneladas/ano, e o início de operação termelétrica da MPX/Eneva. Foram construídas ainda duas fábricas para produção de cimento. Sem contar a ampliação da Vale e das cimenteiras, apenas os dados informados nos estu-

37. Gabarito, na "Minuta de anteprojeto de lei: estabelece normas para o zoneamento, parcelamento, uso e ocupação do solo no município de São Luís", refere-se à altura, em número de andares, que os prédios podem ter, de acordo com as zonas especificas. 
dos de impacto ambiental apresentados pelas empresas Alumar e MPX/Eneva informam um acréscimo anual de 19,3 mil toneladas de poluentes. Em consequência desse alto volume de poluentes, convivemos com a ultrapassagem dos padrões legais de emissão de poluentes na região do distrito industrial, tal como partículas totais em suspensão, partículas inaláveis e óxidos de nitrogênio. Apenas para dar o exemplo, no período de 01/05/2007 a 24/06/2008 o padrão legal de emissão de partículas totais em suspensão, que é de $240 \mu \mathrm{g} / \mathrm{m}^{3}$ em 24 horas, foi ultrapassado 77 vezes no porto do Itaqui. A legislação brasileira admite apenas a ultrapassagem desse padrão uma vez por ano (VIAS DE FATO, set. 2015, p. 4).

Esses dados denunciam diversas irregularidades, como o fato de os órgãos licenciadores ambientais ainda emitirem novas licenças mesmo já ultrapassados os limites e padrões legais; a falta de monitoramento e estudos autônomos por parte do Estado, uma vez que esses dados, mesmo já tão ruins, são apenas informações das próprias empresas, resultados dos seus estudos de impactos ambientais. Quais as reais emissões de poluentes hoje em São Luís? 0 que quer a prefeitura concedendo o aumento de poluentes na atmosfera do município?

0 advogado segue dizendo que:

Além disso, a prefeitura fez uma divulgação apenas protocolar das audiências, que estão acontecendo com público muito baixo. É absurdo que a prefeitura queira aumentar a área do distrito industrial e aumentar o gabarito de construção de prédios para 31 andares sem que a população participe efetivamente desse processo de discussão.

[...] Sem querer ser leviano, acho que os principais beneficiários da proposta apresentada pela Prefeitura são as indústrias e a as empresas de construção civil. Nas audiências já realizadas ficou evidenciado que não houve nenhuma preocupação com fatores importantes como saneamento e mobilidade urbana, por exemplo. [...] A cidade desenhada pela prefeitura com essa proposta empurrará a população pobre cada vez mais para bairros da periferia, com pouca ou nenhuma infraestrutura. [...] A cidade não existe apenas para que uma pequena casta ganhe dinheiro, mas para que todos nela vivam com dignidade (VIAS DE FATO, set. 2015, p. 5).

Um documento-convite assinado por um "coletivo em construção" que questiona a finalidade, a forma e o método das audiências de proposta de alteração da lei afirma que:

Todas essas mudanças propostas vieram à tona nas 13 (treze) audiências já realizadas, que foram convocadas a toque de caixa, sem nenhum empenho institucional na sua ampla divulgação (descumprindo uma exigência legal do Estatuto da Cidade) e com uma metodologia que dificultava a participação dos poucos que chegaram a ter conhecimento de sua realização e acompanharam boa parte desse verdadeiro "faz-de-conta". Assim, a Prefeitura procura apenas cumprir formalmente a realização desses fóruns, previstos por força de lei, deixando de fora questões que interessam verdadeiramente a população, como a necessidade de saneamento básico (que atualmente não chega a 5\% das necessidades atuais da cidade), mobilidade urbana e transporte público de qualidade, bem como quaisquer questões urbanas apresentadas durante as audiências e que estejam fora do roteiro traçado em conluio com industriais e donos de construtoras da cidade ou representantes do empresariado, local 
ou trans/nacional, os principais beneficiados com as alterações pretendidas.

As 2 (duas) últimas audiências públicas previstas não foram realizadas, pois a $14^{\text {a }}$ (décima quarta) audiência, prevista para a Vila Maranhão, contou com uma grande mobilização da Zona Rural II de São Luís e a forte participação popular junto a alegados problemas técnicos inibiu a equipe da Prefeitura de levar a farsa adiante. Assim, aqueles que têm acompanhado o processo aguardam novo edital de convocação das mesmas, que têm assumido grande relevância, pois têm sido ampliados o conhecimento e a mobilização popular sobre o processo. Para maiores informações sobre as audiências realizadas e seus desdobramentos, foi organizado um material que pode ser acessado através de https://sway.com/LXVUYYlzkl9yuHzI (SANT'ANA JÚNIOR, 2015).

Nas audiências públicas, questionadas na forma, no método e no conteúdo por diversos cidadãos, comunidades, entidades da sociedade civil como a CPT, grupos de pesquisa como o GEDMMA, as inúmeras dúvidas sobre quem serão os reais beneficiários da mudança na lei foram expostas pela população, que questionava os representantes da prefeitura.

Os principais questionamentos foram sobre por que tanta pressa da prefeitura em realizar um processo tenso e confuso sobre mudanças tão profundas para toda a cidade; por que as audiências tratavam apenas de questões localizadas sem que se entendesse o todo da proposta; por que a proposta não considera a realidade da metropolização dos municípios da ilha; ${ }^{38}$ por que a proposta não parte das reais e atuais condições de coleta e tratamento de esgoto e resíduos sólidos da cidade, ${ }^{39}$ bem como de fornecimento de água potável à população; por que não se parte da análise da situação caótica do trânsito e transporte público; por que ampliar áreas e os tipos de indústrias mesmo com os padrões de poluição já ultrapassados; por que não apresentar um projeto viável de mobilidade urbana; quais os projetos para os territórios rurais, para a agricultura familiar; quanto das áreas verdes serão preservadas; quantas reservas ambientais serão criadas; qual o lugar da Resex de Tauá-Mirim na proposta.

Esses e inúmeros outros questionamentos acompanharam praticamente todas as audiências públicas já realizadas, para os quais as respostas dos representantes da prefeitura foram sempre evasivas ou, de modo desrespeitoso, procuravam desqualificar ou intimidar os cidadãos. A resposta mais "técnica" e mais bem elaborada se resumia a: "isso não é objeto das audiências públicas, nem dessa proposta”.

Entretanto, como já vimos, a proposta da prefeitura de alteração da Lei de zoneamento, parcelamento, uso e ocupação do solo e do Plano Diretor prevê o adensamento urbano, o aumento de área e tipos de indústrias e a expulsão das comunidades rurais, e omite a política de conservação ambiental.

Com a impossibilidade de dialogar de modo franco com os representantes da pre-

38. A comunidade Vila Madureira foi assentada em Paço do Lumiar (NOGUEIRA, 2010). As comunidades rurais expulsas de São Luís têm, de modo disperso, buscado abrigo nos municípios vizinhos. Diversos empreendimentos residenciais com o foco no mercado de São Luís são construídos em municípios adjacentes, e nenhuma política de metropolização prevê os recíprocos impactos aos municípios.

39. Atualmente somente 5\% do esgoto de São Luís recebe algum tipo de tratamento. Só se faz a coleta seletiva de 4\% dos resíduos sólidos. A falta de água potável é um constante em inúmeros bairros da cidade. 
feitura, vários cidadãos e entidades da sociedade civil organizada passaram a denunciar os atos autoritários e antidemocráticos que tencionavam à aprovação da proposta a todo custo. A CPT formalizou junto ao Ministério Público Federal do Maranhão (MPF/ MA) denúncia de todo o processo, e no dia 29 de setembro de 2015 ocorreu uma reunião na sede do MPF com a participação de representantes da prefeitura, do MPE e da sociedade civil organizada. “A reunião é decorrente de um procedimento apuratório instaurado por representação da Comissão Pastoral da Terra (CPT), que questiona a publicidade do procedimento de revisão e o prejuízo das mudanças para as comunidades rurais de São Luís" ${ }^{40}$. Dessa reunião resultou que o MPF recomendou a suspensão de todo o processo por sessenta dias até que elaborasse nota técnica sobre a matéria.

0 que temos é um processo longo, de décadas, que se apresenta agora como novidade. A mudança dessa lei cumpre consolidar o projeto da elite política e econômica local, coligada com grandes empresas da construção civil e de outras áreas da indústria, em exterminar os territórios rurais e criar um “ambiente de negócios” favorável aos grupos empresariais, sem qualquer cuidado com a vida das pessoas.

Do sítio eletrônico "0 que está por trás da alteração na Legislação Urbanística defendida pela Prefeitura de São Luís?" ${ }^{41}$, que faz um resumo do processo em curso sobre as tentativas da prefeitura em alterar a lei, podemos ver que o projeto vem de longo tempo e que perpassa várias legislaturas municipais:

Uma declaração do próprio presidente do Incid é reveladora de que os interesses - e os interessados - nas alterações das leis que podem alterar radicalmente a cidade ultrapassam as várias gestões pelas quais o município já passou: ele chegou a afırmar que essas são propostas que estão dadas desde o governo Tadeu Palácio, e vêm sendo tocadas de lá para cá, cabendo agora a Edivaldo Holanda Júnior levar-lhes a cabo. Marcelo Espírito Santo destacou que as propostas não são de hoje [...].

Objetivamente, o que temos é um processo tenso e controverso em curso que, se seguir a vontade da prefeitura, deixará São Luís como a própria comunidade Cajueiro, combalida a desaparecer como cidade, e como um local com possibilidades de se viver com dignidade e saúde. Em reunião no MPF/MA, o advogado Guilherme Zagallo afirmou que:

Se a leitura feita pela prefeitura e pelo Incid estiver certa, que se pode aumentar o gabarito dos prédios, a extensão e tipos das indústrias, a diminuição da área rural, então só falta a prefeitura completar seu trabalho, propondo um plano de evacuação da cidade, sim, porque vai ficar inviável viver em uma cidade com essas características e esses índices de poluentes (informação verbal ${ }^{42}$ ).

40. PROCURADORIA DA REPÚBLICA NO MARANHÃO. Assessoria de Comunicação. MPF/MA sedia reunião pra discutir Plano Diretor de São Luís. 01 out. 2015. Disponivel em: <http://www.prma.mpf.gov.br/ noticia-5604>. Acesso em: 15 out. 2015.

41. 0 QUE está por trás da alteração na Legislação Urbanística defendida pela Prefeitura de São Luís? 2015. Disponivel em: <https://sway.com/LXVUYYlzkl9yuHzI>. Acesso em: 15 out. 2015.

42. Guilherme Zagallo em reunião da do dia 29 de setembro de 2015, no MPF/MA. 
Ao tombar a comunidade Cajueiro, suas comunidades irmãs, a proposta de criação da Resex de Tauá-Mirim - áreas de preservação ambiental - e São Luís tombam junto, porque são também essas formas de territorialização que fazem a ilha do Maranhão ser o que é; ceifá-las é ceifar a própria cidade.

Verdade histórica ou não, por que teria Nero ateado fogo em Roma?

\section{Referências}

ADRIANCE, M. C. Terra prometida: as comunidades eclesiais de base e os conflitos rurais. São Paulo: Paulinas, 1996.

ALMEIDA, A. W. B. Amazônia: a dimensão política dos "conhecimentos tradicionais". In: ACSELRAD, H. (Org.). Conflitos ambientais no Brasil. Rio de Janeiro: RelumeDumará; Fundação Heinrich Böll, 2004, p. 37-56.

Os quilombolas e a base de lançamento de foguetes de Alcântara: laudo antropológico. Brasília: MMA, 2006.

ALVES, E. J. P. Repertórios e argumentos da mobilização política: um estudo sobre o Movimento Reage São Luís em São Luís-MA. Rio de Janeiro: UFRJ/IFCS, 2014.

ANDRADE, M. P. (Org.). Expropriação de famílias na periferia de São Luís pelo projeto Carajás. São Luís: Relatório da SMDDH ,1981.

ANDRADE, M. P.; CORRÊA, C. M. Mataram a pobreza: condições de vida de famílias de trabalhadores rurais expropriadas pela Companhia Vale do Rio Doce e assentadas no "morro pelado", em São Luís, Maranhão. Revista Pará Desenvolvimento: a face dos grandes projetos, n. 20/21, Belém, 1986/1987.

ARAÚJO, E. W. F. Na zona rural de São Luís, comunidade do Cajueiro reaje às ameaças da empresa wpr. Blogue do Ed Wilson. 28 out. 2014. Disponivel em: <http://blogdoedwilson.blogspot. com.br/2014/10/na-zona-rural-de-sao-luis-comu-
nidade-do.html\#.VFbQZvnF_wg $>$. Acesso em: 02 nov. 2014.

BOURDIEU, P. 0 desencantamento do mundo: estruturas econômicas e estruturas temporais. São Paulo: Perspectiva, 1979.

BRASIL. Ministério da Cultura. Instituto do Patrimônio Histórico e Artístico Nacional. Relatório de Gestão 2013. Brasília-DF, 28 de março de 2014, $711 \mathrm{p}$.

COMUNIDADE Cajueiro questiona como WPR compra terreno de assentamento do ITERMA para construir porto privado em reserva extrativista. Fórum Carajás. Disponivel em: <http://www.forumcarajas.org.br>. Acesso em: 02 nov. 2014.

DEFENSORIA garante uso da terra e de recursos naturais pela comunidade do Cajueiro. Defensoria Pública do estado do Maranhão. Disponível em: $<$ http://www.dpe.ma.gov.br/dpema/index.php/SiteInstitucional/ver_noticia/3490>. Acesso em: 02 nov. 2014.

DE JESUS, T. S. C. Violência, memória e a resistência: análise do conflito pela terra em Rio dos Cachorros, São Luís-MA (1996-2013). 2014. Monografia (Graduação em História) - Universidade Federal do Maranhão, São Luís, 2014. Mimeo.

DIAGONAL URBANA CONSULTORIA LTDA. Diagnóstico sócio-organizativo. São Luís, 2005. Mimeo.

FEITOSA, R. M. M. Tendências da economia mundial e ajustes nacionais e regionais. Série Debates. São Luís: Mestrado em Políticas Públicas da UFMA, 1998.

FERREIRA, N. A implantação da Alumar e o deslocamento de famílias camponesas: expropriação e relocação em Vila Coquilho. 1997. Monografia (Graduação em. Ciências Sociais) - Universidade Federal do Maranhão, São Luís, 1997.

FERRETTI, S. Querebentã de Zomâdonu: etnografia da Casa das Minas do Maranhão. 3.ed. Rio de Janeiro: Pallas, 2009.

FUNDAÇÃO SOUSÂNDRADE DE APOIO AO DESENVOLVIMENTO DA UNIVERSIDADE FEDERAL 
DO MARANHÃO. Refinaria Premium I: Estudo de Impacto Ambiental e Relatório de Impacto Ambiental (EIA-RIMA). São Luís: FSADU/UFMA, 2009.

GEDMMA. Relatório socioantropológico: RESEX de Tauá-Mirim Cajueiro e outras comunidades tradicionais na luta por justiça e direitos territoriais, Zona Rural II, São Luís: UFMA, 20014.

GISTELINCK, F. Carajás: usinas e favelas. São Luís: Minerva, 1988.

GOMES, A. M. Produção de alimentos e cultura alimentar: avaliação das formas de obtenção e consumo de alimentos em Santana dos Caboclos-MA. Relatório de pesquisa apresentado ao CNPq. São Luís: Grupo de Estudos Rurais e Urbanos, 2004.

HARVEY, D. 0 novo imperialismo. Trad. Adail Sobral e Maria Stela Gonçalves. 6. ed. São Paulo: Loyola, 2012.

INSTITUTO BRASILEIRO DO MEIO AMBIENTE E DOS RECURSOS NATURAIS RENOVÁVEIS. Laudo sócio-econômico e biológico para criação da reserva extrativista do Taim. São Luís: IBAMA, 2006. Mimeo.

MAIA, M. R. S. Diferentes visões de natureza, diferentes usos: os conflitos socioambientais na área proposta para criação da Reserva Extrativista de Tauá-Mirim - Zona Rural de São Luís-MA. 2014. Dissertação (Mestrado em Ciências Sociais) - Universidade Federal do Maranhão, São Luís, 2014.

MENDONÇA, B. R.; MOREIRA, J. F. 0 fator participativo nas audiências públicas em São Luís. 2014. Artigo (Pós-Graduação em Ciências Sociais) - Disciplina de Sociologia e Meio Ambiente, Universidade Federal do Maranhão, São Luís, 2014.

MENDONÇA, B. R. Cajueiro: entre as durezas da vida e do ferro, no tempo do aço. Monografia (Graduação em Ciências Sociais) - Universidade Federal do Maranhão, São Luís, 2006.

MRS - Estudos Ambientais Ltda. Terminal portuário de São Luís: Estudo de Impacto Ambiental/ Relatório de Impacto Ambiental. São Luís: MRS Estudos Ambientais Ltda., 2014.
NASCIMENTO, I. Tempo da natureza e tempo do relógio: tradição e mudança em uma comunidade pesqueira. Boletim do Museu Paraense Emílio Goeldi, Série Antropologia, v. 11, Belém: Museu Goeldi, 1995.

NOGUEIRA, P. M. Projetos de desenvolvimento e conflitos socioambientais em São Luís-MA: o caso da instalação de uma usina termelétrica. 2010. Monografia (Graduação em Serviço Social) - Universidade Federal do Maranhão, São Luís, 2010.

O ESTADO DO MARANHÃO. São Luís: 15 out. 2015.

0 QUE está por trás da alteração na Legislação Urbanística defendida pela Prefeitura de São Luís? 2015. Disponivel em: <https://sway.com/LXVUYYlzkl9yuHzI>. Acesso em: 15 out. 2015.

PEDROSA, L. A. C. A questão agrária no Maranhão. São Luís, em PDF [S/D]. Disponível em: $<$ http://abda.com.br/texto/LuisACPedrosa.pdf>. Acesso em: 14 out. 2015.

PEREIRA, P. M. N. Projetos de desenvolvimento e conflitos socioambientais em São Luís-MA: o caso da instalação de uma usina Termelétrica. 2010. Monografia (Graduação em Serviço Social) - Universidade Federal do Maranhão, São Luís, 2010.

PROCURADORIA DA REPÚBLICA NO MARANHÃO. Assessoria de Comunicação. MPF/MA sedia reunião pra discutir Plano Diretor de São Luís. 01 out. 2015. Disponivel em: <http://www.prma.mpf. gov.br/noticia-5604>. Acesso em: 15 out. 2015.

POPULAÇÃO se revolta contra "jagunços" e interdita a BR-135. O Imparcial, São Luís, 15 out. 2014. Caderno Urbano, p. 1.

RENNÓ, C. Reis do Agronegócio. Interpretação e música: Chico César. In: CÉSAR, C. Estado de poesia. [s.l.]: Laboratório Fantasma, 2015. 1 CD. Faixa 14.

SANT'ANA JÚNIOR, H. A. Carta para entidades plano diretor [mensagem pessoal]. Mensagem recebida por <canapum@gmail.com> em 15 out. 2015. 
SANT'ANA JÚNIOR, H. A.; PEREIRA, M. J. F; ALVES, E. J. P; PEREIRA, C. R. A. (Orgs.). Ecos dos conflitos socioambientais: a RESEX de Tauá-Mirim. São Luís: EDUFMA, 2009.

SECRETARIA MUNICIPAL DE SAÚDE. Relação de localidades por distrito. São Luís, 2004. Mimeo.

SILVA, S. C. Filhos do Taim: estratégias para defesa e uso de um território. 2009. Dissertação (Mestrado em Ciências Sociais) - Universidade Federal do Maranhão, São Luís, 2009.

VELHO, 0. G. Frentes de expansão e estrutura agrária: estudo do processo de penetração numa área da transamazônica. Rio de Janeiro: Jorge Zahar, 1972.

VIAS DE FATO. São Luís: ago./set. 2015. Ano 5, № 60.

VIAS DE FATO. São Luís: ago./set. 2015. Ano 5, № 61.

ZAGALLO, J. G. C. (Org.). Considerações preliminares sobre a implantação de um polo siderúrgico na ilha de São Luís. São Luís, 2004. Mimeo. 
RESUMO

Este artigo apresenta os processos de luta vividos nos últimos dez anos (2005-2015) pela comunidade Cajueiro, situada no município de São Luís - MA, e suas coirmãs. Relatam-se os processos de desarticulação que, combinando ação estatal e empresarial, colocam em risco a sociabilidade, os meios e os modos de vida de comunidades como Cajueiro. Por fim, pontuam-se os relatos de resistência face à lógica de desenvolvimento hegemônico e suas consequências para toda a Ilha do Maranhão.

\section{PALAVRAS-CHAVE}

Relato crítico. Desenvolvimento. Processos de desarticulação. Resistência. Cajueiro. São Luís.

\section{ABSTRACT}

This article presents the struggling processes lived over the past ten years by the community of Cajueiro and its co-sisters in São Luís, MA. It reports the disarticulation processes combining State and businesses action, jeopardize both sociability and means of life of communities such as Cajueiro are analyzed. To sum up, accounts of resistance facing hegemonic development and its consequences for the Island of Maranhão as a whole are pointed out.

\section{KEYWORDS}

Critical report. Development. Disarticulation processes. Resistance. Cajueiro. São Luís. 